\title{
Initial Discussion on the 2015 Revised National High School Mathematics Curriculum of South Korea
}

\author{
Li Zhangpei ${ }^{1}$, Changun Park $^{2}$ \\ 1 Dept. of Education, Pusan National University, Busan, South Korea, lizhangpei@pusan.ac.kr \\ 2 Dept. of Education, Pusan National University, Busan, South Korea, cupark@ pusan.ac.kr
}

\begin{abstract}
This paper bases on the 2015 revised national high school mathematics curriculum of South Korea to discuss the characteristics of academic education and vocational education in South Korea, and establishes the educating model based on curriculum theory and practice. Through a new round of curriculum reforms, South Korea has infiltrated and implemented vocational education into the general education system, further broadening the development of vocational education.
\end{abstract}

Keywords-South Korea; 2015 Revised National Curriculum; High School; Mathematics; Guidance Counselling

\section{INTRODUCTION}

According to the latest data from the International Monetary Fund (IMF) in 2018, Korea's GDP is currently about 15973.9 trillion dollars, ranking 11th in the world. The rapid development of South Korea's economy depends not only on the government's appropriate adjustment of its national economic development strategy, but also on the introduction of advanced technologies. What's more important is that Korea has always attached importance to personnel training and actively promoted the development of human resources.

On May 13, 2015, the Ministry of Education of the Republic of Korea formally issued the notice about the 2015 High School Education Curriculum Standards. The reform, based on the reform and operation of the 2009 education curriculum and aimed at cultivating "integrated creative talents", would make new setting and development to curriculum reforms from elementary to high school education. [1] The establishment of the new curriculum reform closely follows the pace of rapid social development and provides a comprehensive assessment of the curriculum development, curriculum system and curriculum operation of each school. As the new direction of curriculum reform in Korea, the 2015 education curriculum reform is based on equality education to involve vocational education in the general education system and put it into practice, thus laying the foundation for developing independent, innovative and multiculturally literate talents.
The new curriculum reform has enhanced the concept of integrating "humanities, society, and science and technology", and added new integrated and comprehensive subjects such as society and science, which has expanded the options for students cultivated in future career development orientation. [2] The "Core Literacy Curriculum" is the main strategic goal of the 2015 education curriculum reform, gradually extending the focus point from the textbook curriculum to the structuring, collaboration, and participation of the curriculum. From the perspective of students, they have been provided more opportunities to participate in practice, learning experience and interest have been stimulated and the pressure from learning environment has been relieved. From the perspective of school, a stable and safe education and development model has been upheld while cooperating with the establishment of social practice activities.

\section{Changes In Korean High SchOOL Mathematics CURRICULUM IN 2015}

The 2015 education curriculum reform was partially revised from September 23 to December 1st, 2015. In order to further enhance students' interest and confidence in learning mathematics subjects, a new development project course was appropriately set up on the basis of optional mathematics subjects of the 2009 education curriculum reform: Future Course (Career Exploration Course). In order to cultivate more sophisticated and talented individuals, optional subjects such as Practical Mathematics, Economic Mathematics, Mathematics Task Study, Deepened Mathematics I, and II have been added to mathematics subjects to cultivate students' analysis and insight abilities. The new round of curriculum reform in Korean mathematics officially began practicing in 1-2 grade at primary schools nationwide in 2017. In 2018, its scope will extend to courses of 3-4 grade in primary schools, and first grade in junior and senior high schools. In 2019, 5 and 6 grade courses in primary schools will be covered, and in March 2020, it will be officially popularized to all schools from elementary schools to high schools nationwide [1].

The table below shows the curriculum changes in Korea's senior high school mathematics in 2009 and 2015 education curriculum reform. 
TABLE I. COMPARISON BETWEEN CHANGES OF MATHEMATICS IN 2009 AND 2015 MATHEMATICS CURRICULUM REFORM

\begin{tabular}{|c|c|c|c|c|c|}
\hline \multicolumn{3}{|c|}{2009 Education Curriculum Reform } & \multicolumn{3}{|c|}{2015 Education Curriculum Reform } \\
\hline \multirow{5}{*}{$\begin{array}{l}\text { Optional } \\
\text { Subjects }\end{array}$} & \multirow{2}{*}{$\begin{array}{c}\text { Basic } \\
\text { Subjects }\end{array}$} & \multirow{2}{*}{ Basic Mathematics } & Compul & Subjects & \multirow{3}{*}{$\begin{array}{c}\text { Mathematics } \\
\text { Mathematics I, } \\
\text { Mathematics II, } \\
\text { Probability and } \\
\text { Statistics, Calculus }\end{array}$} \\
\hline & & & \multirow{3}{*}{$\begin{array}{l}\text { Optional } \\
\text { Subjects }\end{array}$} & \multirow{2}{*}{$\begin{array}{l}\text { Regular } \\
\text { Subjects }\end{array}$} & \\
\hline & \multirow[b]{2}{*}{$\begin{array}{l}\text { Regular } \\
\text { Subjects }\end{array}$} & \multirow{2}{*}{$\begin{array}{c}\text { Mathematics I, } \\
\text { Mathematics II, } \\
\text { Probability and } \\
\text { Statistics, Calculus I, } \\
\text { Calculus II、Vector } \\
\text { Geometry }\end{array}$} & & & \\
\hline & & & & $\begin{array}{l}\text { Optional } \\
\text { Future } \\
\text { Subjects }\end{array}$ & $\begin{array}{c}\text { Geometry, Practical } \\
\text { Mathematics, Economic } \\
\text { Mathematics, } \\
\text { Mathematics Task } \\
\text { Study, Calculus }\end{array}$ \\
\hline & $\begin{array}{c}\text { Deepened } \\
\text { Subjects }\end{array}$ & $\begin{array}{c}\text { Advanced } \\
\text { Mathematics I、 } \\
\text { Advanced } \\
\text { Mathematics II }\end{array}$ & $\begin{array}{r}\text { Professi } \\
\text { (in scie }\end{array}$ & $\begin{array}{l}\text { Subjects } \\
\text { ic fields) }\end{array}$ & $\begin{array}{l}\text { Deepened Mathematics } \\
\text { I, Deepened } \\
\text { Mathematics II, } \\
\text { Advanced Mathematics } \\
\text { I, Advanced } \\
\text { Mathematics II }\end{array}$ \\
\hline
\end{tabular}

It can be clearly seen from Table 1 that the elective subjects modules have been refined, and Future Courses (Career Exploration Courses) have been newly added in the 2015 new curriculum reform. The Deepened Courses added in 2009 have been changed to professional courses and two new subjects have been opened. The establishment of these subjects is closely related to the scientific fields. The two prominent features of the new curriculum reform in South Korea are: First, it is integrated with the development of the social science; and the second one is the integration of career exploration into the curriculum system. At present, Korea's institutions of higher education have included assessments in social, scientific, and professional subjects in the admission test. For example, Seoul University, Korea University, Yonsei University, etc., refuse to simplify and separate mathematics tests. Instead, they advocate the integration of mathematics courses with the development of social science.

\section{CHARACTERISTICS OF THE ELECTIVE Future COURSE}

The Future Course (진로과정), also called Career Exploration Course, is the most representatively characteristic development course in 2015 Korean education curriculum reform. Historically, South Korea began to study future education since 1982. The Korean Institute for Educational Development launched a heated discussion and profound study of future education courses in 1990, defining it as "the implementation of general vocation-adaptation education" and "diverse business education". In the same year, the Ministry of Education set future education as a core area of "technique and industry", "future and enterprise", etc.

The course, as a breakthrough point for the entrance of vocational education into the general education model, is an integrated education of individual and social development, which is mainly embodied in that students can independently choose appropriate courses according to their own interests and hobbies, and that the foundation for deciding the direction of future career planning has been laid, providing students with more possibilities for personal future career development. In the future course, the mathematics subjects are not single and independent anymore, but are transformed into social learning courses that are more related to social life such as practical subjects including Practical Mathematics, Economic Mathematics, and Mathematics Task Study. At the same time, high school students are better prepared for studying mathematics in colleges and universities. In other words, mathematics evaluation is not only limited to written evaluations in textbook theories, but changes into the combination of theoretical and practical evaluations.

According to Korea's top 100 schools announced in January 2018, 23 of the ordinary high school schools have implemented their courses in advance. [1] For example, there is an independent entrance education instruction center in the school, the operation develops career prospects to explore the curriculum, and conducts research and evaluation. In terms of teachers, there is also a professional team of teachers. In terms of the design of the curriculum, the school strongly promotes discipline activities and produces students' individual-stage storybooks (Story Making). In addition to theoretical courses, schools now add more activity-based courses. Students set personal future career orientation through on-campus course activities. In the compiling work of the Future Course, the humanities and social subjects have been transformed into social, ethical and natural subjects. Mathematics subjects are also reflected in science integration courses, life science courses and natural science courses. The school has different set points for different subjects such as basic courses, deepened courses, general education courses and vocational courses. During the design project of future courses, various schools hold exchange meetings to actively discuss the students' questions and difficulties in their future career development. 


\section{DISCUSSION AND INSPIRATION OF THE NEW CURRICULUM REFORM}

In consideration of the educational funds in China and South Korea, in 2016, the total investment in education in China was 3.8866 trillion yuan while the national financial education funds were 3.1373 trillion yuan with a year-on-year increase of $7.36 \%$. [3] South Korea's total budget for the Ministry of Education in 2017 was approximately 3.2538 trillion yuan (54.8973 trillion won). In South Korea, in addition to educational funds from government, there are economic supports from different types of industrial chains in various regions. There is a lot of room for stability in the training of talents. According to China's National Education Development Situation in 2016, there were 24,700 high schools with 23.6665 million students. In Korea, as of 2016, there were 2,353 regular high schools with $1,752,457$ students. What perplexes us is that in 2016 Korea's enrollment rate of higher (undergraduate) education from high schools was $69.8 \%$, with a decrease of $1 \%$ compared to 2015 . In fact, there was a plummeting reduction of enrollment rate from 2011 to 2016, dropping sharply from $72.5 \%$ in 2011 . One of the reasons is that high school graduates do not regard the college entrance examination as a life barrier, but rather focus on their career preference. The selection of Chinese college entrance examination and the examination of its content still do not deviate from the tendency of knowledgeoriented with excessive absolutism.

The curriculum reform refers to the task of transforming the previous curriculum organization and designing a new one. It needs to continuously improve with the constant development of society [4]. High school education is the later or advanced stage of secondary education and is also the bond connecting compulsory education and higher education. The development level of high school students greatly influences the quality of all types of talents, professionals and even the entire national citizens. The purpose of the curriculum reform is to identify problems and make suggestions to gradually enhance the idea of "evaluation is research" and "evaluation is the construction of cooperative value" with the promotion of curriculum reform.

South Korea integrates the Future Course (Future Career Exploration Course) into the general high school education curriculum, serving as an opportunity to incorporate the content of vocational education into the general education system. Its legal support first appeared in Korea's Education Law in 1976, making the industry enter junior and senior high schools in order. Later, the Korean government successively formulated a series of mid- and long-term plans, such as the Five-Year Plan for Vocational and Technical Education (19581962), the Five-Year Plan for Science and Technology Education (1967-1971), and the Supply of Science and Technology Talents Plan (1973-1981) and so on, to fully realize the legislative protection mechanism for the development of vocational education.
China's National Med- and Long-term Education Reform and Development Plan Outline (2010-2020) points out that we must create conditions to set up a variety of elective courses to provide students with more choices and to promote the comprehensive and individualized development of students. Active research studies, community services and social practices should be carried out. The diversified development of regular high schools and the diversification of training modes should be promoted and new approaches to discover and train innovative talents should be explored. Eligible regular high schools should be encouraged to appropriately add instructional content of vocational education based on social needs to provide development plans such as vocational education for students and graduates who have not yet graduated [3].

High school curriculum reform and college entrance examination reform complement each other, thus the principles and goals to be followed in each curriculum reform are to meet the requirements of quality education. In other words, the reform of the college entrance examination conducted in parallel with the reform of the new high school curriculum plays a crucial role in the full and effective implementation of the new curriculum reform in high schools and is one of the key factors for the success of the new curriculum reform in senior high schools. Taking Shandong Province as an example. Shandong province, one of the earliest experimental provinces in the new curriculum reform of high schools, has obtained recognition to a certain degree for a series of educational and teaching concepts advocated by the curriculum reform such as the establishment of personalized course selection and selection instruction system for students and the comprehensive and dynamic growth record manuals for students. Currently there are 3231 schools of various types and levels in Qingdao, of which 65 are regular high schools. The gross enrollment rate in high school reached 98\%. In 2016, the Qingdao Comprehensive Education Reform Plan (2016-2020) was announced, and the public property expenditure on education reached 25.083 billion yuan, accounting for $18.54 \%$ of expenditure budget of public property.

A regular-vocational pilot program was established in 6 vocational schools and 4 regular high schools to promote the "further integration" of vocational education and industry, the characteristic development of diversified regular high schools and to "enhance the exchange of quality courses among schools", thus introducing a number of regular high schools featuring humanities, science and technology, oceanography, and foreign languages. Students have been provided with alternative and suitable education. The social practice education has been enhanced and scientific evaluation of education has been promoted to transfer students to substantial edge of human resources. This is the reform of overall structure of the curriculum evolving from a decentralized one to the integrated one, the content of education changing from an academic to a living one and the teaching method changing from injection type to one that respects learners' self-activity. 


\section{CONCLUSION}

Senior high school education is of special significance to improving the quality of citizens and cultivating innovative talents. "No thousand-mile travel can be achieved without single small steps. No rivers or seas will form without the accumulation of water from small streams". Education curriculum reform cannot be completed overnight. It needs to be steadily promoted in a gradual and orderly manner. China and South Korea are geographically close and have similar cultural connections. There have been frequent exchanges since ancient times. "Rocks from other mountains could be utilized to make jades". We should learn from the beneficial experience of the Korean education curriculum reform. To conform to the development trend of the future society, we should reflect on our education system and curriculum content in all aspects, intensify curriculum reform and focus on cultivating students' core qualities, such as self-learning ability, self-reliance and adaptability to society.

\section{REFERENCES}

[1] Ministry of Education of Korea, refer to http://www.moe.go.kr/newsearch/search.jsp

[2] H. J. Lee. A Study on the Mathematics Teachers' Perceptions of the 2015 Revised High School Mathematics Curriculum. Master's Thesis, Korea National University of Education. 2018.

[3] Ministry of Education of the People's Republic of China, refer to http://www.moe.gov.cn/srcsite/A01/s7048/201007/t20100729_171904.h $\mathrm{tml}$

[4] R. Q. Huang \& Y. M. Huang. The Characteristics and Enlightenment of Vocational Education's Legislation in Korea After World War II. Journal of Anhui Business College of Vocational Technology, Vol. 3, No. 1, pp. 64-69, March 2004. 